\title{
FORMATIVE METHOD FOR THE DEVELOPMENT OF ENVIRONMENTAL BEHAVIOR IN UNIVERSITY STUDENTS LIMA- PERU
}

\author{
Jessica Lagos Videla \\ Univesity National University Federico Villarreal EUPG-UNFV, Lima, (Perú). \\ Universidad tecnológica del Perú UTP, (Perú). \\ E-mail: C21402@utp.edu.pe ORCID: https://orcid.org/0000-0003-1991-4171
}

Doris Esenarro Vargas

Univesity National University Federico Villarreal EUPG-UNFV, Lima, (Perú).

E-mail: desenarro@unfv.edu.pe ORCID: https://orcid.org/0000-0002-7186-9614

Garmen Aquije

University Tecnologica de Lima Sur - UNTELS - (Perú).

E-mail: caquije@untels.edu.pe ORCID: https://orcid.org/0000-0002-7622-4882

Jorge Bringas

Univesity National University Mayor de San Marcos, Lima, (Perú). E-mail: jbringass@unmsm.edu.pe ORCID: https:// orcid.org/0000-0003-2011-4964

Recepción: 03/09/2021 Aceptación: 11/11/2021 Publicación: 24/11/2021

\section{Citación sugerida:}

Lagos, J., Esenarro, D., Aquije, C., y Bringas, J. (2021). Formative method for the development of environmental behavior in university students Lima-Peru. 3C Empresa. Investigación y pensamiento crítico, 10(4), 107-125. https://doi. org/10.17993/3cemp.2021.100448.107-125 


\section{ABSTRACT}

This research aims to determine the influence of the method of the formative project in the development of environmental behaviors in undergraduate students of a private university, 2020. This is because in the current educational system, teaching focused on developing competencies was established in the midnineties; despite this, some private academic centers can follow the traditional model for the fulfillment of objectives. The use of the formative project method, which is characterized by its permissibility feature, for which a plan of action is designed, data was collected through a questionnaire based on the Likert scale before and after the application of the project with a sample of 168 students. The results based on the Wilcoxon Ranges statistical analysis showed that there were no students with Low scores in the pre-test, but students with a Medium level of 44.05\% (74); and 55.95\% (94) presented a High level, and in the post-test, the number of Medium levels decreased by 3.57\% (6) and the High level increased by $96.43 \%$ (162) students. They conclude that the method of the formative project influences the environmental behavior and concerning the dimensions of the Practices and improves the behavior of the students either in the recognition and analysis of the problem, the approach, and formulation of strategies.

\section{KEYWORDS}

Method of training projects, Environmental behavior, Eco-efficient practices, Environmental identity. 


\section{INTRODUCTION}

The exercise of teaching should be transcendent since higher education is not absent from research and with it the continuous improvement of methods and processes to optimize this task; that is why, at present, different didactic methods and techniques are analyzed and evaluated to achieve significant learning. (Ambrosio \& Silvano, 2018) According to those above, the present research emphasized the use of the formative project method, which is characterized by its characteristic of allowing students to develop capacities such as observation, analysis of the different problems in their personal, interpersonal, community, work, and ecological context; therefore, a plan of action is designed, and when it is executed, it generates viable solutions, by allowing an autonomous position with initiative and collaborative character. That is why the environmental approach of using the project method in the Environmental Culture course (present in the curriculum of all professional schools in the institution where the research was carried out) will allow students, in the exercise of their profession, to evaluate the impact of their actions on the environment (Ambrosio \& Silvano, 2018).

In our country's educational system, teaching focused on developing competencies was established in the mid-nineties; however, until today, there are private academic centers within the regular primary education that follow the traditional model by fulfilling objectives (Amigo et al., 2018).

In the efforts of the "Ministry of Education" to train teachers nationwide on competency-based education, we can observe the free calls on the Minedu platform on the content of the National Curriculum Design, as well as other documents such as the curriculum framework, the "framework of good teaching and management performance", records that guide and orient uniformly the education we want for our country (Barcelo, 2018). 


\section{METHOD}

\subsection{QUANTITATIVE APPROACH}

Quantitative: It "uses data collection to test hypotheses based on the numerical measurement and statistical analysis to establish patterns of behavior and test theories." (Villamil, 2018)

\subsection{RESEARCH DESIGN}

The design for the present research is "pre-experimental," based on pre-and post-tests. In addition, it is worth mentioning that the Method of formative projects has been used to study its effect on the dependent variable Responsible environmental behavior and to measure the influence of the dependent variable on the independent variable; a pre-test will be carried out before starting the Environmental Culture course with this methodology and a post-test at the end of the academic semester (Caceres, 2018).

"Pre-test and Post-test with a single group":

Where: GE: G1 $\quad$ G1

GE: "Experimental Group"

G1: "Pre-test group."

G2: "Post-test group"

E: "Stimulus" (Application of the Formative Project Method)

\subsection{POPULATION AND SAMPLE}

The total population of students in the VII cycle receiving the environmental culture course consisted of 297 students, while the sample consisted of 168 students (Carmona et al., 2017). To calculate the size of the piece, which is extracted from the population, the following formula was applied: 


$$
n=\frac{n_{o}}{1+\frac{n_{o}}{N}} \quad \text { where: } n_{o}=p^{*}(1-p) *\left(\frac{z\left(1-\frac{\alpha}{2}\right)}{d}\right)^{2}
$$

Formula 1. Sample size.

Where:

$\mathrm{n}=$ sample size

$\mathrm{Z}=$ Confidence level at $95 \%$, which is equal to 1.96

$\mathrm{N}=$ Size of the population (297 students)

$\mathrm{p}=$ Probability of occurrence $(0.5)$

$a=$ confidence level $(95 \%)$

\section{RESULTS}

Table 1. Kolmogorov-Smirnov One Sample Test.

\begin{tabular}{|c|c|c|c|}
\cline { 2 - 4 } \multicolumn{1}{c|}{} & PRETEST & POSTEST & DIFERENCES \\
\hline N & 168 & 168 & 168 \\
\hline Media & 101,29 & 123,90 & 22,61 \\
\hline Dev. Deviation & 14,281 & 10,717 & 15,775 \\
\hline Variance & 203,942 & 114,858 & 248,861 \\
\hline Z $($ K $-\mathrm{S})$ & 0,067 & 0,080 & 0,111 \\
\hline P value &, 066 &, 011 &, 000 \\
\hline
\end{tabular}

Source: own elaboration.

In Table 1, we can observe that the p-value is, 000 and less than 0.05 , the sample does not have a normal distribution; therefore, a non-parametric test can be applied to discredit the hypotheses, in this case, the "Wilcoxon Ranges Non-parametric Test" (Cardona, Velez \& Tobon, 2016).

The "formative projects method" significantly influences the development of responsible environmental behavior, in the dimension eco-efficient practices, in the dimension environmental identity, in the 
dimension environmental awareness in undergraduate students of the VII cycle - Los Olivos - 2018 (Colombo, Rusca and Quiroz, 2016; Carmona et al., 2017).

Table 2. Comparative Analysis of the Environmental Behavior Variable.

\begin{tabular}{|c|c|c|c|c|}
\hline \multicolumn{5}{|c|}{ Test } \\
\hline & & & Pre Test & Pos Test \\
\hline \multirow{4}{*}{$\begin{array}{l}\text { Environmental } \\
\text { Behavior }\end{array}$} & \multirow{2}{*}{ Medium } & Frequency & 74 & 6 \\
\hline & & $\%$ total & $44,0 \%$ & $3,6 \%$ \\
\hline & \multirow{2}{*}{ High } & Frequency & 94 & 162 \\
\hline & & $\%$ total & $56,0 \%$ & $96,4 \%$ \\
\hline \multicolumn{3}{|c|}{ Total } & 168 & 168 \\
\hline
\end{tabular}

Source: own elaboration.

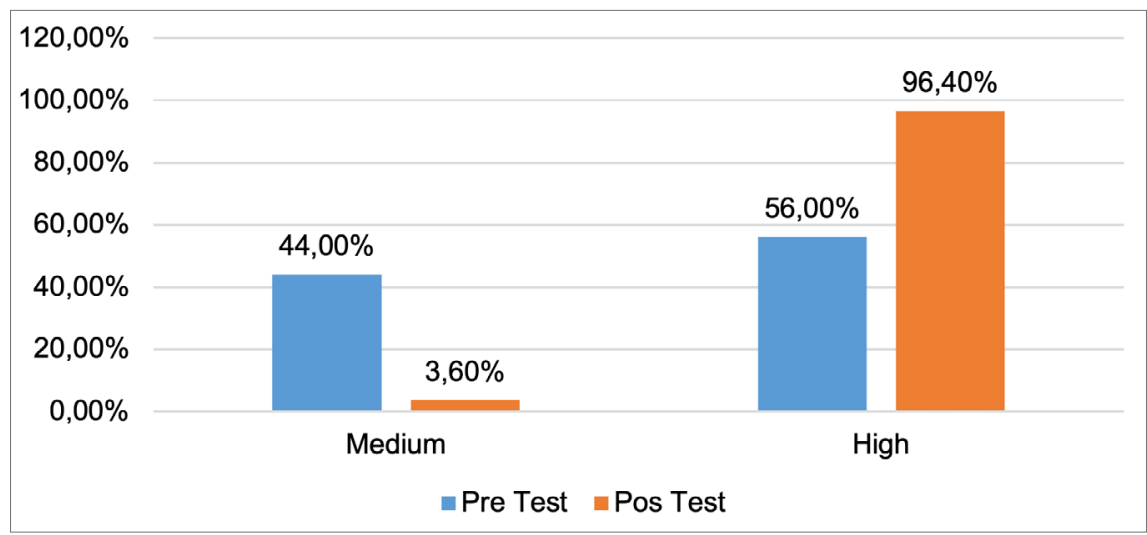

Figure 1. Graph of the Comparative Analysis of the Environmental Behavior Variable.

Source: own elaboration.

The data obtained in Figure 1 shows that, due to the application of the formative project method, the students improved their scores. In the pre-test, there were almost equal amounts of students with scores of Medium and High levels (De la Cruz \& Mamani, 2015). Then with the application of the formative project, the number of students with scores of High level increased and less amount of Medium level; therefore, this method influences the improvement of the Environmental Behavior of the undergraduate 
students of the VII cycle - district Los Olivos, which is visualized in Table 2 and Figure 1 (Florez \& Quebranta, 2017).

In the case of the variable "Method of Formative Projects," as part of the evaluation by the teacher in charge of the Environmental Culture course, the following Table 3 and Figure 2 show the compliance and development of the indicators of the program to demonstrate its influence on the environmental behavior of the students (Fong, Acevedo \& Severiche, 2016; Gomez \& Tobon, 2017).

Table 3. Assessment of the achieved level of the capability Promotes a culture of sustainability through actions related to the care and defense of the environment.

\begin{tabular}{|c|c|c|c|c|c|}
\cline { 3 - 6 } \multicolumn{1}{c|}{} & Frequency & \% & \% Valid & Cumulative \% \\
\hline \multirow{3}{*}{ Valid } & In Process & 4 & 2,4 & 2,4 & 2,4 \\
\cline { 2 - 6 } & Achieved & 75 & 44,6 & 44,6 & 47,0 \\
\cline { 2 - 6 } & Highlighted & 89 & 53,0 & 53,0 & 100,0 \\
\hline
\end{tabular}

Source: own elaboration.

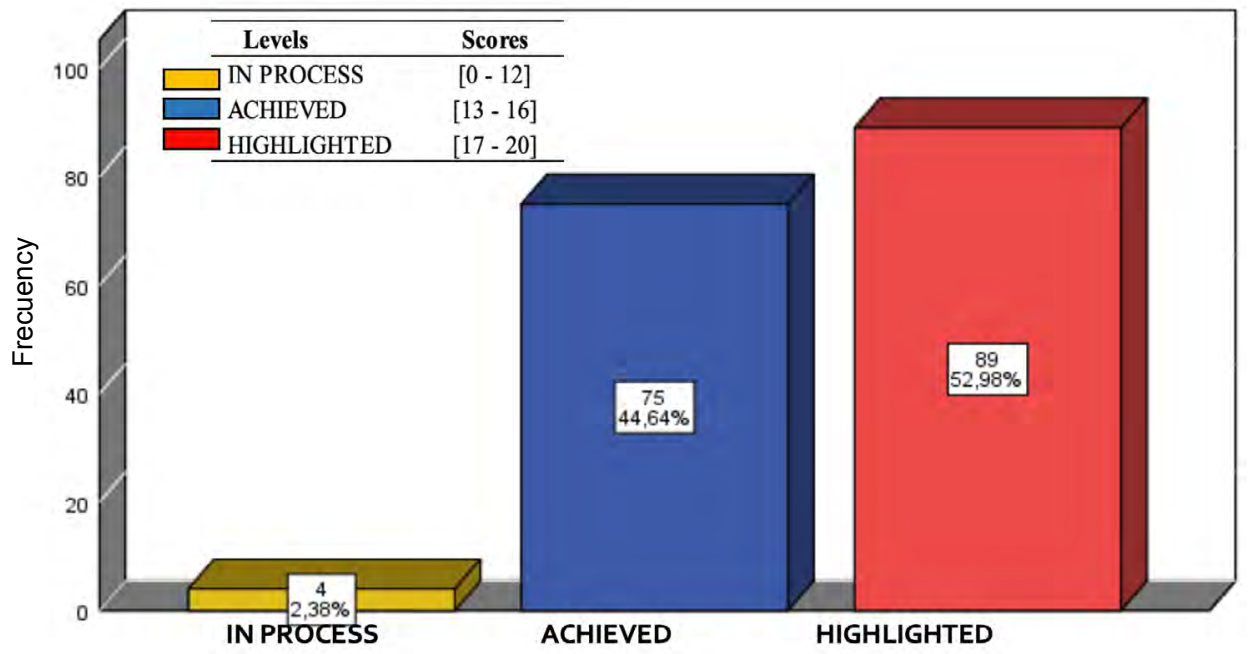

Figure 2. Evaluation of the level achieved for the skill "Promotes a culture of sustainability through actions related to the care and defense of the environment.

Source: own elaboration. 
With the information in Table 3 and Figure 2, we have the average post-test scores of the students evaluated concerning the skill "Promotes the culture of sustainability through actions related to the care and defense of the environment to guarantee ecological well-being, valuing the balance between the individual and his or her social environment"; of which 2.38\% (4) are still In Process, 44.64\% (75) of them in the Achieved level and a majority of 52.96\% (89) of them presented an Outstanding level concerning the capacity analyzed. This questionnaire is part of the evidence of the evaluation process during the Environmental Culture course by the teacher (Gonzales, 2017; Huaylla, 2019).

Table 4. Comparative analysis of the Eco-efficient Practices dimension.

\begin{tabular}{|c|c|c|c|c|}
\hline \multicolumn{5}{|c|}{ Test } \\
\hline & & & Pre Test & Pos Test \\
\hline \multirow{6}{*}{$\begin{array}{c}\text { Eco-efficient } \\
\text { Practices }\end{array}$} & \multirow{2}{*}{ Low } & Frequency & 1 & \\
\hline & & $\%$ total & $0,6 \%$ & \\
\hline & \multirow{2}{*}{ Medium } & Frequency & 68 & 7 \\
\hline & & $\%$ total & $40,5 \%$ & $4,2 \%$ \\
\hline & \multirow{2}{*}{ High } & Frequency & 99 & 161 \\
\hline & & $\%$ total & $58,9 \%$ & $95,8 \%$ \\
\hline \multicolumn{3}{|c|}{ Total } & 168 & 168 \\
\hline
\end{tabular}

Source: own elaboration.

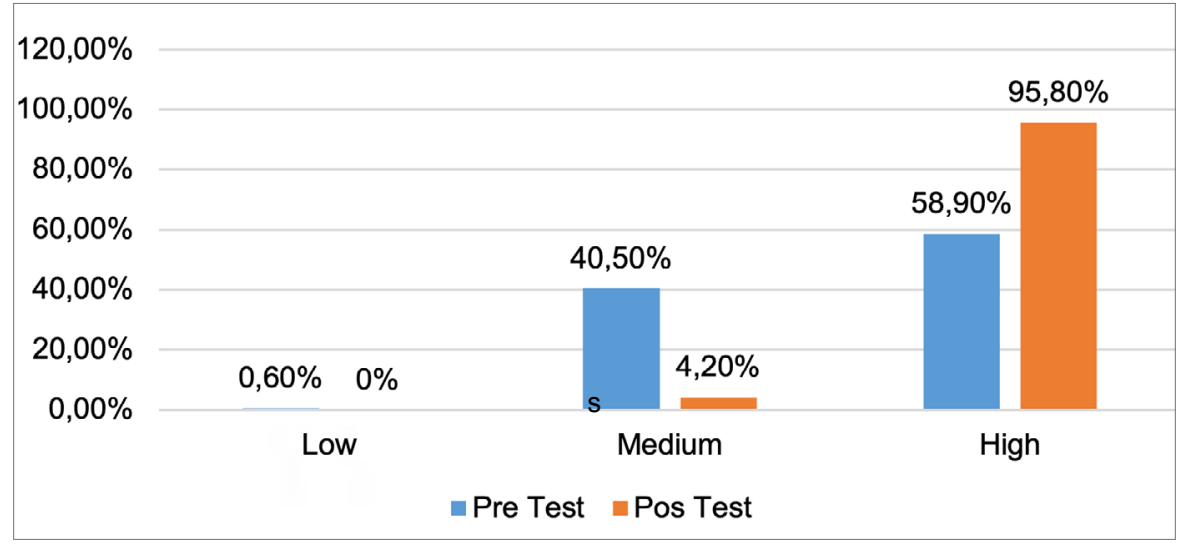

Figure 3. Graph of the Comparative Analysis of the Eco-efficient Practices dimension.

Source: own elaboration. 
Concerning the data obtained, it can be observed that, due to the application of the training project method, the students improved their scores, since in the pre-test there were scores at Low, Medium, and High levels and that with the application of the training project the number of students went on to have scored at Medium level and with a more significant number at High level. Therefore, this method influences the improvement of the Eco-efficient Practices dimension of the undergraduate students of the VII cycle - Los Olivos district, which is visualized in Table 4 and Figure 3 (Ibarra, Segredo \& Juarez, 2018).

Table 5. Comparative analysis of the Environmental Identity dimension.

\begin{tabular}{|c|c|c|c|c|}
\hline \multicolumn{5}{|c|}{ Test } \\
\hline & & & Pre Test & Pos Test \\
\hline \multirow{4}{*}{$\begin{array}{l}\text { Environmental } \\
\text { Identity }\end{array}$} & \multirow{2}{*}{ Medium } & Frequency & 60 & 11 \\
\hline & & $\%$ total & $35,7 \%$ & $6,5 \%$ \\
\hline & \multirow{2}{*}{ High } & Frequency & 108 & 157 \\
\hline & & $\%$ total & $64,3 \%$ & $93,5 \%$ \\
\hline \multicolumn{3}{|c|}{ Total } & 168 & 168 \\
\hline
\end{tabular}

Source: own elaboration.

In Table 5, which is visualized, therefore, this method influences the improvement of the Environmental Identity dimension of the undergraduate students of the VII cycle - Los Olivos district. 


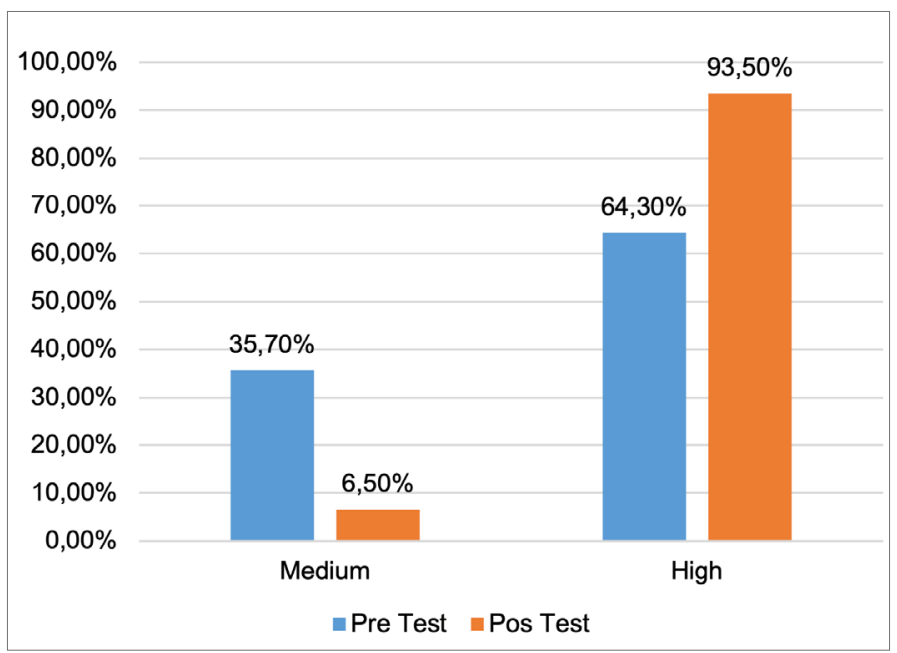

Figure 4. Graph of the Comparative Analysis of the Environmental Identity dimension.

Source: own elaboration.

Concerning the data obtained, it can be observed that the students improved their scores due to the application of the formative project method (Ibarra, Segredo \& Juarez, 2018). Being so that in the pretest, there were scores of Medium and High and that with the application of the constructive project, most students went on to have scores of High level and fewer in the Medium level; and Figure 4 (Juarez \& Torres, 2016).

Table 6. Comparative analysis of the Environmental Awareness dimension.

\begin{tabular}{|c|c|c|c|c|}
\hline \multicolumn{5}{|c|}{ Test } \\
\hline & & & Pre Test & Pos Test \\
\hline \multirow{6}{*}{$\begin{array}{l}\text { Awareness } \\
\text { Environmental }\end{array}$} & \multirow{2}{*}{ Low } & Frequency & 1 & \\
\hline & & $\%$ total & $0,6 \%$ & \\
\hline & \multirow{2}{*}{ Medium } & Frequency & 90 & 18 \\
\hline & & $\%$ total & $53,6 \%$ & $10,7 \%$ \\
\hline & \multirow{2}{*}{ High } & Frequency & 77 & 150 \\
\hline & & $\%$ total & $45,8 \%$ & $89,3 \%$ \\
\hline \multicolumn{3}{|c|}{ Total } & 168 & 168 \\
\hline
\end{tabular}

Source: own elaboration. 
Table 6 visualized this method influences the improvement of the dimension "Environmental Awareness" of the undergraduate students of the VII cycle - Los Olivos district.

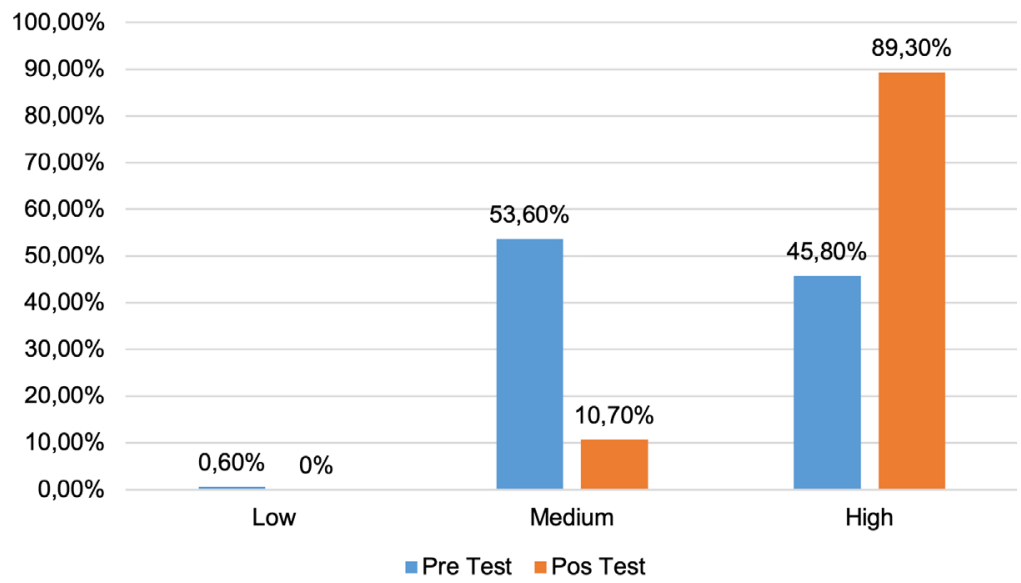

Figure 5. Graph of the Comparative Analysis of the Environmental Awareness dimension.

Source: own elaboration.

Figure 5 show the data obtained; it can be observed that, due to the application of the formative project method, the students improved their scores, being so that in the pre-test, there were scores of Low, Medium and High and that with the application of the formative project the number of students went on to have scored only High and Medium level (Leyva, Inante \& Alonso, 2019; Martinez, 2015; Martinez, 2017; Modejar \& Vargas, 2018).

\section{DISCUSSION}

To begin this section, we will start with the general objective obtained, as a result, the acceptance of the general hypothesis (Moyano et al., 2017; Musitu, Leon, \& Callejas, 2019) states, "The method of formative projects significantly influences the development of responsible environmental behavior in undergraduate students of the VII cycle - Los Olivos - 2018", using the Wilcoxon Ranks Test, thus 
determining that these data differ with the application of the project, in favor of this (Paredes et al., 2017; Porras \& Perez, 2019).

Therefore, from the above mentioned, according to the studies already conducted both internationally and nationally that have been found as reference for the development of this study, there is a relationship and concordance with this research work. The research found as Colombo, Velez, and Tobon (2016), agrees with the results obtained since they specify that "there is a high level of satisfaction with the methodology used, while the breakdown of the logbook attesting to the successful implementation of the proposed mechanism concerning the attitude and performance achieved (Rivera \& Garces, 2018). In the same way, it was possible to identify possibilities for improvement that could be given to future implementations or modifications", this statement is related since it mentions that the methodology of formative projects is adequate, beneficial, and successful when applied.

Similarly, it agrees with Amérigo, Garcia, and Cortes (2017). They state in their documentary analysis that "such projects should be conceived as didactic strategies that should be oriented towards the ability to develop competencies based on being able to identify, argue, interpret and solve various problematic issues under the approach of the proposal of the contents based on entrepreneurship proposals and the development of their context", which shows that "formative projects" methodologically speaking influence the improvement of students in different areas (Rivera \& Garces, 2018).

Furthermore, Acuña and Severino (2018) states that the "formative projects methodology has significantly influenced in the substantial improvement in front of solving context problems in students of the secondary level," as it reveals concordance with the present research thus corroborating, that the method of the formative project influences the student in their behavior as other aspects.

In this section, the specific hypotheses accepted to be mentioned below are: the first specific hypothesis "The method of formative projects significantly influences the dimension eco-efficient practices in undergraduate students of the VII cycle - Los Olivos - 2018. "In this case, the research related to this 
result was by Colombo el al. (2016), who states that "the learning supported by the methodology of the formative projects integrated to the curriculum allows concatenating transcendent facts of the student's context, enabling a lasting learning obtained from their formative experience", since this developed research agrees in some way since as a formative project it will have a positive response and part of this is in the student's behavior, whatever the subject matter is (Rodriguez, Mendoza \& Cargua, 2019; Vanegas et al., 2018).

\section{CONCLUSIONS}

The program used based on the formative project significantly influences environmental behavior, which was evidenced in the results, not having students with scores of Low level, but Medium level with 74 $(44.0 \%)$ and High level with $94(56.0 \%)$ students; according to the post-test the results differed in favor of the application of the formative program presenting a decrease of students with scores of Medium level with $6(3.57 \%)$ mainly passing with scores of High level 96.43\% (162). This demonstrates the effectiveness of this method and its implementation in institutions, thus improving the role of people in the environmental field.

The methodology of training projects used and applied to the dimension of Eco-efficient Practices presented a result with respect to the pre-test of $1(0.6 \%)$ student in the "Low level," 68 (40. In the case of the post-test, there were no students in the "Low level," 7 (4.2\%) in the "Medium level," and 161 $(95.8 \%)$ in the "High level," all this shows that after the application of the training project, the dimension of Eco-efficient Practices improved in the students and therefore there is a significant influence on this dimension.

According to the Environmental Identity dimension that has been tested, in the pre-test, there were no students with "Low level," 60 (35.7\%) students with "Medium level," 108 (64.3\%) students in the "High level"; for the post-test, there were no students with "Low level," 11 (6.5\%) students with "Medium level" and $157(93.5 \%)$ students with "High level" — concluding that the formative project methodology 
influences environmental behavior leading to the dimension of Environmental Identity in students, which complies and works positively and the importance of the proper methods in the formation of students in the environmental field.

Finally, for the dimension of Environmental Awareness, the result obtained in the pre-test there was $1(0.6 \%)$ student in the "Low level," $90(53.6 \%)$ in the "Medium level," and 77 (45.8\%) students with "High level"; for the post-test, the result obtained was that there were no students with Low scores, but there were 18 (10.7\%) students with "Medium level" and 150 (89.3\%) students with "High level." The conclusion is that the training method is positive and that its application is booming since the results show that after carrying out the training project, most of the students scored high; that is, it influences the dimension of Environmental Awareness, which is part of the Environmental behavior.

\section{REFERENCES}

Acuña-Moraga, O., \& Severino-González, P. (2018). Sustentabilidad y comportamiento del consumidor socialmente responsable. Opción, 34(87), 299-324.

Ambrosio, R., \& Silvano, J. (2018). Aprendizaje por proyectos, una experiencia socioformativa. Voces de la Educación, 3(5), 3-19.

Amérigo, M., García, J., \& Côrtes, P. (2017). Análisis de actitudes y conductas pro-ambientales: un estudio exploratorio con una muestra de estudiantes universitarios brasileños. Ambiente \& Sociedade, 20(3), 1-20. http://doi.org/10.1590/1809-4422asoc300r1v2032017

Amigo, G., Labraña, J., Cortés, J., Gómez, E., Moreno, J., \& Muñoz, M. (2018). Hacia una educación ambiental para una sociedad compleja. Un análisis desde la teoría de sistemas sociales. Revista Mad(39), 13-45. http:/ /doi.org/10.5354/0718-0527.2019.53283 
Barcelo, C. (2018). Conciencia ambiental y comportamiento ecológico. Un análisis de la escala GEB (General Ecological Behavior) de Kaiser. Revista internacional de sociología, 60(33), 133-170. https:// doi.org/10.3989/ris.2002.i33.733

Gáceres, F. (2018). Proyectos formativos y resolución de problemas contextualizados en estudiantes del cuarto grado del nivel secundario de la Institución Educativa Fuan Andrés Vivanco Amorín, Ate-2017. Tesis de maestría, Universidad Nacional de Educación. http://repositorio.une.edu.pe/handle/UNE/1821

Cardona, S., Vélez,J., \& Tobón, S. (2016). Contribución de la evaluación socioformativa al rendimiento académico en pregrado. Educar, 52(2), 423-447. https://doi.org/10.5565/rev/educar.763

Carmona, B., Aguilar, M., Barrios, D., \& Calvo, A. (2017). Predictive capacity of environmental identity and values on the recycling of glass: effect of environmentalism and appreciation of nature. Psyecology, 8(2), 149-176. https://doi.org/10.1080/21711976.2017.1291184

Collado, S., Senís, J., \& Fidalgo, G. (2018). Innovando en la Universidad para acercarnos a un desarrollo sostenible. Edunovatic.

Colombo, G., Rusca, I., \& Quiroz-Ghura, A. (2016). Estudio observacional del comportamiento proambiental de separación de residuos en origen en estudiantes universitarios. Universidad de Buenos Aires.

De la Cruz, M., \& Mamani, O. (2015). Las actividades de aprendizaje en el diseño de los proyectos del área de comunicación de una institución educativa del nivel secundario de la ciudad de Pasco (Tesis de maestría). Lima.

Flórez, E., \& Quebrada, A. (2017). Proyectos formativos ambientales, como estrategias didácticas para el fortalecimiento de la cultura ambiental, de los estudiantes de básica primaria en Institución Educativa INECI (Tesis de licenciatura). Universidad de Córdoba. 
Fong, W., Acevedo, R., \& Severiche, C. (2016). Estrategia de investigación formativa en educación tecnológica: el caso del Proyecto Integrador. Itinerario Educativo: revista de la Facultad de Educación, 30(67), 103-121. https://dialnet.unirioja.es/servlet/articulo?codigo=6280495

Gómez-GonzálezJ. \& Tobón, S. (2017). Análisis documental de los proyectos formativos en Educación Básica. Metodología, experiencias y beneficios. Revista Atlante: Cuadernos de Educación y Desarrollo. http:/ /hdl.handle.net/20.500.11763/at

González, G. (2017). Las competencias y el enfoque socioformativo: Una propuesta para transformar la educación. En S. Tobón (Coord.), Foro de Evaluación Socioformativa. https: / /www.researchgate.net/ publication/322220515_Las_Competencias_y_el_Enfoque_Socioformativo_Competencies_ and_the_Socioformative_Aproach

Huaylla, J. (2019). Proyecto formativo para el desarrollo de la conciencia ambiental de los estudiantes del $4^{\circ}$ Grado de secundaria de la Institución Educativa Mariscal Cáceres de Huamanga (Tesis de maestría). Universidad Nacional de Educación Enrique Guzmán y Valle, Lima.

Ibarra, S., Segredo, S., \& Juárez, L. Y. (2018). Estudio de validez de contenido y confiabilidad de un instrumento para evaluar la metodología socioformativa en el diseño de cursos. Revista Espacios, 39(53). http:/ / www.revistaespacios.com/cited2017/cited2017-24.pdf

Juárez, P., \& Torres, G. (2016). Proyectos formativos de investigación: análisis de una experiencia. Revista Atlante: Cuadernos de Educación y Desarrollo. http:/ / hdl.handle.net/20.500.11763/ATLANTE2016-07-proyectos

Leyva, P., Infante, A., \& Alonso, L. (2019). Los proyectos escolares: alternativa para desarrollar la formación laboral. Opuntia Brava, 11(2), 1-13. https://doi.org/10.35195/ob.v11i2.736

Martínez, I. (2015). Identidad ambiental: La construcción de un concepto a partir del análisis de la plataforma Pro-Río (Tesis de doctorado). Universidad de Alicante, España. 
Martínez, R. (2017). Ensayo crítico sobre educación ambiental. Revista Electrónica Diálogos Educativos, 12(24), 74-104.

Mondéjar, J., \& Vargas, M. (2018). Modelos de comportamiento ambiental en economía ecológica: Una revisión bibliográfica. Estudios de economía aplicada, 336(1), 309-316. https://dialnet.unirioja. es/servlet/articulo? codigo $=6283930$

Moyano, E., Palomo, G., Olivos, P., \& Sepúlveda, J. (2017). Ambientes naturales y urbanos determinan creencias y comportamientos ambientales, el pensamiento económico y la felicidad. Psyecology, 8(1), 75-106. http://doi.org/10.1080/21711976.2016.1272875

Musitu, D., León, C., \& Callejas, J. (2019). Un análisis socioeducativo de la Educación Ambiental y del Aula Natura. RES: Revista de Educación Social, (28), 59-78. https://dialnet.unirioja.es/servlet/ articulo? codigo $=6877386$

Paredes, I., Sansevero, I., Casanova, I., \& Ávila, M. (2017). Aprendizaje-servicio. Metodología para el desarrollo de competencias integrales en la educación superior. Opción: Revista de Ciencias Humanas y Sociales, (84), 634-663. https:/ / dialnet.unirioja.es/servlet/articulo?codigo=6402385

Porras, Y., \& Pérez, M. (2019). Identidad ambiental: múltiples perspectivas. Revista Científica, 34(1), 123-138. https://doi.org/10.14483/23448350.14003

Rivera, P., \& Garcés, C. (2018). Desarrollo del comportamiento proambiental en los individuos y sus determinantes. REIS: Revista Española de Investigaciones Sociológicas, (163), 59-78.

Rodríguez, A., Mendoza, M., \& Cargua, N. (2019). El proyecto integrador de saberes una oportunidad para aprender a aprender. EmásF: revista digital de educación fisica, 62-77. https:// dialnet.unirioja.es / servlet/articulo? codigo $=6860154$ 
Vanegas, M., Ortega, P., Bustos, J., \& Corral, V. (2018). Desarrollo de la Escala Expectativa de Comportamiento Ambiental de Otros con adultos jóvenes mexicanos. Universitas Psychologica, 17(2), 49-58. http://doi.org/10.11144/javeriana.upsy17-2.deec

Villamil, L. (2018). Propuesta didáctica de educación ambiental para el desarrollo de la conciencia y el conocimiento ambiental (Tesis de Maestría). Universidad de Ciencias Aplicadas y Ambientales, Bogotá. 
